\title{
Pengarusutamaan Pengurangan Resiko Bencana (PRB) Berbasis Kurikulum Pendidikan Agama Islam
}

\author{
Rubaidi \\ Universitas Islam Negeri Sunan Ampel Surabaya \\ robertmugabe@yahoo.com
}

\begin{abstract}
This paper thoroughly discusses the role of Islamic education institutions in Disaster Risk Reduction (DRR). This field-based research paper takes the locus of MIN Jejeran, Pleret, Bantul, Yogyakarta. The program adapted from Kemendiknas policies takes "Sekolah Siaga Bencana" as the theme. In the midst of disaster phenomena in various regions in Indonesia, MIN Jejeran not only plays an active role in DRR conceptually in the form of integration of Islamic Religious Education (PAI) curriculum, but also increases the level of action in the field. This paper limits only photographing the Earthquake of PRB integration effort into the PAI curriculum to international recognition. This reseach contributes the role of Islamic educational institution to the disaster risk reduction.
\end{abstract}

\section{Keywords: affirmative action; disaster risk reduction; Islamic education teaching}

\begin{abstract}
Abstrak
Tulisan ini menelaah peran lembaga pendidikan Islam dalam Pengurangan Resiko Bencana (PRB). Tulisan yang didasarkan riset lapangan ini mengambil lokus MIN Jejeran, Pleret, Bantul, Yogyakarta. Program yang mengadaptasi kebijakan Kemendiknas mengambil tema besar "Sekolah Siga Bencana." Di tengah fenomena bencana di berbagai daerah di Indonesia, MIN Jejeran tidak hanya berperan aktif dalam PRB secara konseptual dalam bentuk integrasi kurikulum Pendidikan Agama Islam (PAI), melainkan juga tataran aksi di lapangan. Tulisan ini membatasi hanya memotret upaya integrasi PRB Gempa Bumi ke dalam kurikulum PAI hingga mendapat pengakuan dunia internasional. Riset ini memberi kontribusi terhadap peran penting lembaga pendidikan (Islam) dalam konteks edukasi disaster risk reduction (DRR).
\end{abstract}

\section{Kata kunci: pendidikan Agama Islam; pengurangan resiko bencana}

\section{A. Pengantar}

Studi tentang peran lembaga pendidikan dalam kaitannya dengan pengurangan resiko bencana (PRB) telah banyak memberi kontribusi konkrit dalam kehidupan nyata. Tidak hanya berbasis lembaga pendidikan saja. Lebih dari itu, peran dunia pendidikan dalam konteks kebencanaan telah masuk hingga ke dalam berbagai disiplin ilmu seperti IPA, IPS, Matematika, Bahasa Indonesia, dan seterusnya. ${ }^{1}$ Bahkan, isu tentang bencana telah masuk (mainstreaming) ke dalam kurikulum pendidikan di beberapa sekolah. ${ }^{2}$ Pengarusutamaan bencana ke dalam kurikulum dengan mata pelajaran IPA, IPS, dan seterusnya ini telah dilakukan di salah satu SMP di Panti, Jember, sebagai daerah yang pernah mengalami bencana banjir bandang dan tanah longsor. ${ }^{3}$ Di antara studi-studi kebencanaan dalam relasi dengan lembaga pendidikan di atas, belum banyak yang terkait dengan lembaga pendidikan Islam maupun materi keislaman.

${ }^{1}$ Leli Honesty dan Nazwar Djali, "Pendidikan Kebencanaan Di Sekolah - Sekolah Di Indonesia Berdasarkan Beberapa Sudut Pandang Disiplin Ilmu Pengetahuan”, Jurnal Momentum, Vol. 12, No. 01, (Pebruari 2012): 52-55.

${ }^{2}$ Mirza Desfandi, "Urgensi Kurikulum Pendidikan Kebencanaan Berbasis Kearifan Lokal di Indonesia", Jurnal Sosio Didaktika, Vol. 1, No. 2 (Desember 2014): 192-197.

${ }^{3}$ Iswatul Hasanah, Sri Wahyuni, Rayendra Wahyu Bachtiar,'Pengembangan Model Mitigasi Bencana berbasis Potensi Lokal yang Terintegrasikan ke dalam Kurikulum IPA di SMP”, Jurnal Pendidikan Fisika, Vol. 5, No. 3 (Desember 2016): 226-231. 
Tulisan ini secara khusus akan menelaah peran lembaga pendidikan Islam maupun Islam sebagai doktrin di Yogjakarta.

Bencana Gempa Bumi di Yogyakarta, 27 Mei 2006 menyadarkan para pihak. Meskipun kekuatan Gempa Bumi tercatat hanya 5,9 skala richter, tetapi gempa tersebut sebagai gempa terhebat yang pernah menimpa Yogyakarta. Peristiwa Gempa Bumi Yogyakarta menjadi "laboratorium" bencana bagi para pihak (stakeholder) terkait dengan isu bencana. Pusat studi kebencanaan lahir di berbagai perguruan tinggi di Yogyakarta. UGM sebagai PTN tertua akhirnya melahirkan jurusan magister (S2) khusus dengan konsentrasi kebencanaan. Gunung Merapi, sebagai gunung teraktif di dunia juga menjadi salah satu pusat studi kegunung-apian di Indonesia. $^{4}$

Selain pusat-pusat studi kebencanaan, beberapa lembaga pendidikan di Yogyakarta juga mengambil kebijakan strategis dalam upaya Pengurangan Resiko Bencana (PRB) bagi para siswa. Langkah strategis ini penting bagi upaya preventif mengurangi tingkat kerentanan (vulnerability) masyarakat (siswa) dalam menghadapi bahaya (hazard) di masa mendatang. Kebijakan strategis PRB bagi lembaga pendidikan ini sangat penting merujuk beberapa peristiwa bencana yang terjadi di jam efektif kerja. Gempa bumi di Pakistan pada bulan Oktober 2005 merenggut lebih dari 16 ribu anak-anak meninggal akibat runtuhnya gedung sekolah. Longsor lahan di Leyte, Philipina menewaskan lebih dari 200 anak sekolah. ${ }^{5}$ Akan halnya gempa di Yogyakarta, gempa ini terjadi pada pukul 05.54 pagi, saat kegiatan belajar mengajar belum berlangsung. Padahal jumlah sekolah di seluruh DIY yang roboh mencapai 277, terdiri dari; 101 TK, 148 SD, 16 SMP, dan 12 SMA/SMK/MAN. ${ }^{6}$

Tulisan ini merujuk kepada pengalaman lembaga pendidikan (sekolah) MIN Jejeran, Pleret, Bantul, Yogyakarta yang mengintegrasikan PRB ke dalam kurikulum Pendidikan Agama Islam (PAI). PRB berbasis kurikulum Pendidikan Agama Islam (PAI) MIN Jejeran ini sebagai bentuk respons terhadap kebijakan PRB Kementerian Pendidikan Nasional yang mengadaptasi UU Nomor 24 Tahun 2007 tentang Penanggulangan Bencana. ${ }^{7}$ Konsep PRB di MIN Jejeran dimaksud mencakup kebijakan, kerangka, strategi, perencanaan, pembelajaran pada peserta didik; atau pun menyusun dan mengembangkan kegiatan-kegiatan pencegahan, mitigasi bencana dan kesiapsiagaan bencana dalam kurikulum pendidikan. ${ }^{8}$ Kebijakan Kemendiknas dalam upaya PRB dikenal luas salah satunya dengan program "Sekolah Siaga Bencana."

Secara faktual, MIN Jejeran, Pleret, Bantul, Yogyakarta merupakan fenomena menarik terkait PRB. Upaya PRB yang dilakukan oleh MIN Jejeran mendapat justifikasi pada acara "Asian Ministerial Conference on Disaster Risk Reduction (AMCDRR) ke-5 yang

\footnotetext{
${ }^{4}$ Meskipun Gempa Bumi hanya 5,9 skala richter, menurut data Departemen Sosial, korban meninggal sebanyak 4.983 jiwa meninggal. 1 jam paska gempa beredar isu tsunami. Jalan-jalan macet akibat warga berhamburan keluar rumah untuk menyelamatkan diri. Para warga mencari tempat yang tinggi. Bahkan para korban yang dirawat di rumah sakit berhamburan keluar dengan membawa infus di tangannya. Selain itu, ribuan rumah, gedung perkantoran, dan Mall rusak para seta roboh. Lihat: IDN Times, 5 Hal Mengenai Gempa Bumi Yogyakarta Pada Tahun 2006. http://www.rappler.com/indonesia/134463. Diunduh pada tanggal 15 Mei 2017.

${ }^{5}$ Krisna S Pribadi, “Konsep Pengelolaan Bencana”, Makalah TOT Pengelolaan Resiko Bencana Berbasis Pesantren Nahdlatul Ulama, Pusat Mitigasi Bencana ITB Bandung, 2007, h. 2

${ }^{6}$ Krisna S Pribadi, Konsep Pengelolaan Bencana, Makalah TOT Pengelolaan ....., h. 3

${ }^{7}$ Secara tegas Kemendiknas melalui Direktoral Jenderal Management Pendidikan Dasar dan Menengah merumuskan kebijakan PRB dengan beberapa tujuan pokok, di antaranya adalah; (a) Menumbuhkembangkan nilai dan skip kemanusiaan; (b) Menumbuhkembangkan sikap dan kepedulian terhadap resiko bencana; (c) Mengembangkan pemahaman tentang resiko bencana, kerentanan sosial, fisik, perilaku dan motivasi; (d) Meningkatkan pengetahuan dan ketrampilan untuk pencegahan dan pengurangan resiko bencana;..... Lihat: Direktorat Jenderal Management Pendidikan Dasar \& Menengah, Strategi Pengarusutamaan Pengurangan Resiko Bencana di Sekolah, (Jakarta: Kementerian Pendidikan Nasional, 2010), h. 14-15.

8 Direktorat Jenderal Management Pendidikan Dasar \& Menengah, Strategi Pengarusutamaan Pengurangan Resiko Bencana di Sekolah, (Jakarta: Kementerian Pendidikan Nasional, 2010), h. 14-15.
} 
diselenggarakan di Jogja Expo Center (JEC), Yogyakarta, 22-25 Oktober 2012 yang dihadiri oleh menteri-menteri se-Asia-Pasifik. Di sela-sela kesibukan delegasi para menteri se-Asia Pasific dalam konferensi dimaksud, MIN Jejeran menjadi salah satu lokasi yang mereka kunjungi untuk menyaksikan simulasi tanggap bencana. Bahkan, MIN Jejeran juga berhasil menjuarai perlombaan mitigasi bencana se-Asia Pasifik. ${ }^{9}$ Keberhasilan MIN Jejeran dalam PRB ini memang tidak berdiri sendiri. Selain pihak Kemendiknas, terdapat lembaga donor international yang memiliki andil besar bagi prestasi MIN Jejeran, yakni Plan Internasional.

Praktek kebijakan PRB berbasis kurikulum Pendidikan Agama Islam (PAI) MIN Jejeran memiliki justifikasi kuat baik secara konsep maupun praktek. Dasar legitimasinya tidak lain adalah secara geografis, posisi Indonesia yang dikelilingi oleh ring of fire (cincin api) ${ }^{10}$ sehingga memiliki ancaman besar dengan banyaknya gunung berapi dan potensi gempa bumi. Gempa bumi misalnya, sejauh ini belum ada teknologi yang mampu memprediksi kapan dan dimana gempa akan terjadi. Dengan memberikan pengetahuan dan keterampilan tentang kebencanaan kepada siswa, resiko timbulnya korban dalam jumlah besar saat jam belajarmengajar bisa dihindari. Karena itulah pengalaman PRB di MIN Jejeran memiliki makna strategis untuk ditulis agar bisa ditransformasikan kepada para pihak.

\section{B. Pengarusutamaan PRB dalam Kurikulum Nasional}

Pemerintah, melalui Menteri Pendidikan Nasional sejak 2010 telah memberi perhatian serius terhadap isu bencana. Dalam Surat Edaran (SE) Menteri Pendidikan Nasional No.70a/SE/ MPN-/2010 tentang Pengarusutamaan Pengurangan Resiko Bencana di Sekolah, Mendiknas menghimbau kepada seluruh Gubernur, Bupati dan Walikota di Indonesia untuk menyelenggarakan penanggulangan bencana di sekolah melalui 3 hal yaitu: (1) Pemberdayaan peran kelembagaan dan kemampuan komunitas sekolah, (2) Pengintegrasian PRB ke dalam Kurikulum Satuan Pendidikan Formal, baik intra maupun ekstra kurikuler, (3) Membangun kemitraan dan jaringan antar pihak untuk mendukung pelaksanaan PRB di sekolah. ${ }^{11}$

Sikap pemerintah ini dapat dimaknai sebagai follow up dari berbagai keputusan dunia internasional. Upaya ini merupakan wujud nyata dari dukungan United Nations Development Programme (UNDP), Badan Nasional Penanggulangan Bencana (BNPB) dan Konsorsium Pendidikan Bencana (KPB) kepada Kementerian Pendidikan Nasional yang telah dimulai sejak tahun 2008. Bentuk kepedulian terlihat melalui penyusunan Strategi Pengarusutamaan Pengurangan Resiko Bencana di sekolah yang menjadi lampiran beserta modul ajar pengintegrasian PRB yang disusun oleh Pusat Kurikulum sebagai pedoman dalam penyelenggaraan PRB di sekolah.

Pengarusutamaan PRB ke dalam kurikulum sekolah memiliki tujuan jangka pendek dan panjang. Tujuan jangka pendek untuk membuat anak-anak lebih aman saat terjadi bencana dan menjadikan mereka sebagai agen perubahan yang dapat menyebarkan pengetahuan kepada kalangan yang lebih luas terutama keluarga mereka sendiri. Tujuan jangka panjang untuk

${ }^{9}$ Harian Kedaulatan Rakyat, “Delegasi Kementerian se-Asia Pasifik ke MIN Jejeran”, terbit tanggal 23 Oktober 2012, h. 4.

${ }^{10}$ Ring of fire adalah daerah yang sering mengalami gempa bumi dan letusan gunung berapi yang mengelilingi cekungan Samudera Pasifik. Daerah ini berbentuk seperti tapal kuda dan mencakup wilayah sepanjang $40.000 \mathrm{~km}$. Daerah ini juga sering disebut sebagai sabuk gempa Pasifik. Lihat Fakhri, Fakhrizal. "Berada di Ring of Fire, ESDM Sebut Seluruh Wilayah Indonesia Rawan Gempa". OKEZONE NEWS, Rabu 03 Oktober 2018.Diunduh tanggal 5 Oktober 2018.

${ }^{11}$ Surat Edaran Menteri Pendidikan Nasional No.70a/SE/ MPN-/2010 ini merupakan tindak lanjut dari amanat UU No. 24 Tahun 2007 tentang Penanggulangan Bencana dan Peraturan Pemerintah No. 21 Tahun 2008 tentang penyelenggaraan penanggulangan bencana serta arahan Presiden kepada Menteri Pendidikan Nasional dan Menteri dalam Negeri untuk mendorong daerah untuk memasukkan pendidikan kebencanaan ke dalam kegiatan intra dan ektra kurikuler. 
mempersiapkan anak-anak sebagai generasi masa depan dengan pengetahuan pencegahan, mitigasi dan kesiapsiagaan terhadap bencana.

Para pakar bencana berpendapat bahwa anak-anak adalah aset negara yang perlu dilindungi sebagai investasi bagi generasi masa depan. Sekolah merupakan tempat dimana anak-anak menghabiskan sebagian besar waktunya. Sekretaris Direktorat Jenderal Manajemen Pendidikan Dasar dan Menengah, Kemendiknas Dr. Sutanto, S.H., M.A. juga menyatakan, perlu menjadikan sekolah sebagai tempat yang aman terhadap bencana sekaligus tempat anakanak mempelajari pengetahuan tentang cara penyelamatan diri dan mengurangi resiko bencana di lingkungannya. Hal ini penting karena seringkali bencana terjadi pada saat jam belajar ketika anak-anak berada di sekolah.

Kebijakan PRB di sekolah dasar dan menengah membantu anak-anak memainkan peranan penting dalam penyelamatan hidup dan perlindungan anggota masyarakat pada saat kejadian bencana ${ }^{12}$. Menyelenggarakan pendidikan tentang resiko bencana ke dalam kurikulum sekolah sangat membantu dalam membangun kesadaran akan isu tersebut di lingkungan masyarakat. Sebagai tambahan terhadap peran penting mereka di dalam pendidikan formal, sekolah juga harus mampu melindungi anak-anak dari suatu kejadian bencana alam. Investasi dalam memperkuat struktur gedung sekolah sebelum suatu bencana terjadi, akan mengurangi biaya/anggaran jangka panjang, melindungi generasi muda penerus bangsa, dan memastikan kelangsungan kegiatan belajar-mengajar setelah kejadian bencana.

Sosialisasi melalui lembaga pendidikan tentang resiko bencana dan keselamatan di sekolah merupakan dua prioritas utama untuk dilakukan. Hal ini termaktub dalam Kerangka Kerja Aksi Hyogo (Hyogo Frame Works) yang telah diadopsi oleh 168 negara, termasuk Indonesia. Pengintegrasian PRB ke dalam kurikulum pendidikan secara nasional dan penyediaan fasilitas sekolah yang aman dan menyelamatkan juga merupakan dua prioritas yang memberikan kontribusi terhadap kemajuan suatu negara menuju tujuan pembangunan milenium (millenium development goal). ${ }^{13}$ Sasaran utama kampanye ini adalah mempromosikan integrasi resiko bencana dalam kurikulum sekolah di negara-negara yang rawan bencana alam. Selain itu juga mempromosikan konstruksi yang aman dan penyesuaian gedung sekolah yang mampu menahan bahaya. Untuk mencapai sasaran tersebut diperlukan langkah-langkah yang tepat dengan cara mempromosikan praktek terbaik, bagaimana bermanfaatnya pendidikan dalam mengurangi resiko bencana dan keselamatan di sekolah bagi masyarakat yang rentan.

Sosialisasi, edukasi, serta kampanye ditujukan kepada para pihak (stakeholder) sekolah. Para pihak ini meliputi murid, guru, pembuat kebijakan pendidikan, orangtua, insinyiur, ahli bangunan, dan sebagainya. Selain itu juga ditujukan kepada lembaga pemerintah yang bertanggung jawab atas isu manajemen bencana, Mendiknas, para pemimpin politik di tingkat nasional, pembuat keputusan di masyarakat, dan otoritas lokal. Pesan yang bisa disampaikan antara lain: (1) pendidikan tentang resiko bencana dapat menguatkan anak-anak dan membantu membangun kesadaran yang lebih besar dalam masyarakat; (2) fasilitas bangunan sekolah yang bisa menyelamatkan hidup dan melindungi anak-anak sebagai generasi penerus bangsa dari suatu kejadian bencana alam; dan (3) pendidikan tentang resiko bencana dan fasilitas keselamatan di sekolah akan membantu negara-negara menuju ke arah pencapaian tujuan pembangunan millenium. ${ }^{14}$

Berbagai upaya pemerintah lambat laun membuahkan hasil menggembirakan. Masyarakat, khususnya dalam hal ini para peserta didik di lembaga pendidikan formal

12 Aldila Rahma, "Implementasi Program Pengurangan Risiko Bencana (Prb) Melalui Pendidikan Formal”, Jurnal Varia Pendidikan, Vol. 30, No. 1, (Juli 2018): 1-11

${ }^{13}$ www.id.wikipedia.org/wiki/Tujuan_Pembangunan_Milenium. Diakses pada tanggal, 26 November 2016.

${ }^{14}$ Keterangan selengkapnya mengenai Tujuan Pembangunan Milenium lihat: MDGs Support Unit, Millenium Development Goals, (Jakarta: UNDP, t.t.). 
mendapat manfaat secara langsung. Hasil yang diharapkan antara lain; (1) pemerintah pusat dan daerah menanamkan investasinya dalam fasilitas bangunan sekolah tahan bencana dan mengarahkan kurikulum pendidikan tentang resiko bencana secara nasional; (2) meningkatkan kesadaran sebagai dampak positif adanya pendidikan tentang resiko bencana dan keselamatan di sekolah; dan (3) peningkatan aksi dan penggunaan praktek-praktek yang baik untuk mengerahkan koalisi dan kemitraan, membangun kapasitas sumberdaya yang ada untuk mengadakan pelatihan pendidikan tentang resiko bencana dan keselamatan di sekolah.

Pendidikan PRB sendiri memuat dua tema besar. Pertama, adalah pendidikan PRB Dalam konteks bencana alam. Kedua, pendidikan PRB dalam konteks bencana sosial, yakni konflik kekerasan. ${ }^{15}$ Bencana tidak selalu identik dengan bencana alam (natural disaster) tetapi juga bencana buatan manusia (man-made disaster) dalam hal ini konflik sosial dan terorisme. ${ }^{16}$ Namun, dalam perkembangannya, konflik sosial ${ }^{17}$ dan terorisme ${ }^{18}$ dikeluarkan dalam jenis bencana setelah lahirnya Undang-Undang (UU) baru tentang penangan konflik sosial dan terorisme yang berdiri sendiri. Karena itu, edukasi kepada peserta didik dirasa mendesak dilakukan oleh pemerintah.

Pendidikan PRB dimaknai sebagai peningkatan kapasitas siswa dalam memahamai kebencanaan. Pra-syarat menjadi Sekolah Siaga Bencana harus memenuhi beberapa parameter pengurangan resiko berbasis sekolah yang digunakan antara lain: (1) kebijakan pendidikan untuk mempromosikan pengurangan resiko, (2) pengurangan resiko dengan pendekatan remaja sebaya, (3) lingkungan sekolah yang sehat dan aman, (4) rencana kontingensi pengurangan resiko di sekolah dan upaya pengurangan resiko berbasis sekolah yang mendukung peningkatan kesehatan dan kesiapsiagaan masyarakat. ${ }^{19}$

Integrasi PRB dalam kurikulum nasional diterapkan mulai jenjang pendidikan SD/MI hingga SMA/MA. Dalam penerapannya integrasi PRB tidak dijadikan sebagai mata pelajaran tersendiri, tetapi diintegrasikan ke dalam mata pelajaran yang memuat materi yang terkait dengan PRB, antara lain mata pelajaran Agama, IPA, IPS, Sains, Bahasa Indonesia, Matematika, dan mata pelajaran yang lain. Untuk merealisasikan visi di atas, perlu dilakukan prinsip-prinsip dasar, yaitu; (1) Mendukung prioritas dan program pemerintah pusat maupun pemerintah daerah dalam PRB, (2) Menggunakan prinsip-prinsip desentralisasi pendidikan, (3) Memperhitungkan perspektif gender dalam perencanaan dan pelaksanaan program, (4) Meningkatkan kapasitas/kemampuan sumber daya di tingkat sekolah, tingkat gugus sekolah maupun tingkat pemerintah kabupaten/kota dalam pelaksanaan misi PRB, (5) Menjalin kerjasama dan melibatkan pemerintah secara aktif, dan terakhir (6) Menjalin kerjasama dengan LSM, institusi pendidikan dan penelitian, dan media, serta sektor swasta. ${ }^{20}$

${ }^{15}$ Pada awalnya jenis bencana secara keseluruhan sebanyak 14 bencana. Ke-14 jenis bencana dimaksud meliputi; (1) Volcano (gunung merapi), (2) Earthquake (gempa bumi), (3) Flood (Banjir), (4) Hurricane (angin topan/badai), (5) Conflict (konflik horisontal/sosial), (6) Terrorism (terorisme), (7) Enviroment polution (polusi lingkungan), (8) Drought (kekeringan), (9) Industrial accident (bencana industri), (10) Tsunami, dan (11) Transportation accident (bencana transportasi), (12) Kekeringan, (13) Tanah longsor, (14) Kebakaran. Lihat: Undang-Undang Nomer 24 tahun 2007 tentang Penanggulangan Bencana.

16 Seefudin Amsa, "sekolah-berbasis-pengurangan-resiko-bencana mungkin- kah" www.umum.kompasiana.com/2009/05/25/ -6223.html. Diakses tanggal, 28 Desember 2016.

${ }^{17}$ Lihat Undang-undang (UU) Nomer 7 tahun 2012 tentang Penanganan Konflik Sosial. Dengan lahirnya UU No 7 tahun 2012 ini, bencana sosial tidak lagi dimasukkan ke dalam jenis bencana seperti sebelum lahirnya UU ini.

${ }^{18}$ Lihat: Undang-undang (UU) Nomor 9 tahun 2013 tentang Pencegahan dan Pemberantasan Tindak Pidana Pendanaan Terorisme.

${ }^{19}$ Konsorsium Pendidikan Bencana Indonesia, Kerangka Kerja Sekolah Siaga Bencana, (Jakarta: KPB, 2011), h. 30.

${ }^{20}$ Ariantoni, dkk., Modul Pelatihan Pengintegrasian Pengurangan Resiko Bencana (PRB) ke Dalam Sistem Pendidikan, (Jakarta: Pusat Kurikulum Balitbang Kemendiknas, 2009), h. 53-54. 
Prioritas pilihan yang akan diberikan adalah sebagai berikut; (1) Mengintegrasikan PRB ke dalam mata pelajaran dari kurikulum yang berjalan, (2) Mengintegrasikan PRB ke dalam muatan lokal dari kurikulum yang berjalan, (3) Mengintegrasikan PRB ke dalam kegiatan ekstra kurikuler dari kurikulum yang berjalan, (4) Menyelenggarakan mata pelajaran yang telah terintegrasi PRB untuk muatan lokal dibawah kurikulum baru berbasis PRB, serta (5) Membuat kegiatan ekstra kurikuler PRB di bawah kurikulum baru berbasis PRB. ${ }^{21}$ Lembaga pendidikan sebagai stakeholder PRB merespon positif terhadap kebijakan pemerintah ini. Tercatat, sejak 2010 banyak instistusi sekolah, mulai mengadopsi kebijakan PRB ke dalam institusi sekolah. Tercatat sekitar 28 sekolah siaga bencana yang didirikan di Aceh, sekolah siaga bencana Pertiwi I dan 12 sekolah siaga bencana lainnya di Padang, dan sekolah siaga bencana MIN Jejeran Bantul di Yogyakarta. ${ }^{22}$

\section{Integrasi PRB Gempa Bumi dalam Kurikulum Pendidikan Agama Islam (PAI)}

Integrasi PRB Gempa Bumi ke dalam kurikulum dimaksud memang belum mengacu kepada Kurrikulum 2013 yang terkenal dengan istilah K13. Integrasi dimaksud masih mengacu kepada Kurikulum Tingkat Satuan Pendidikan (KTSP). Kurikulum Tingkat Satuan Pendidikan merupakan sebuah perwujudan dari amanat Undang-undang RI No. 20 Tahun 2003 tentang Sistem Pendidikan Nasional. Sebagaimana dijelaskan dalam pasalnya yang ke-1 ayat 11 , kurikulum adalah seperangkat rencana dan pengaturan mengenai isi dan bahan pelajaran serta cara yang digunakan sebagai pedoman penyelenggaraan kegiatan belajar mengajar. ${ }^{23}$ Dengan kata lain, kurikulum pendidikan merupakan suatu perangkat rencana dan pengaturan mengenai tujuan, kompetensi dasar, materi standar, dan hasil belajar, serta cara yang digunakan sebagai pedoman penyelenggaraan kegiatan pembelajaran untuk mencapai kompetensi dasar dan tujuan pembelajaran. ${ }^{24}$ Adapun kurikulum Pendidikan agama Islam, merupakan sebuah usaha sadar dan terencana dalam menyiapkan peserta didik dalam meyakini, memahami, menghayati, dan mengamalkan ajaran Islam melalui kegiatan bimbingan, pengajaran dan pelatihan. ${ }^{25}$

Keberadaan kurikulum PAI mempunyai fungsi dan peran signifikan yang mungkin tidak dimiliki oleh kurikulum lain. Fungsi dimaksud antara lain; Pertama, sebagai fungsi pengembangan. Kurikulum PAI berupaya mengembangkan dan meningkatkan keimanan dan ketakwaan peserta didik kepada Allah SWT. yang telah ditanamkan dalam lingkungan keluarga. Kedua, fungsi penyaluran. Kurikulum PAI berfungsi menyalurkan peserta didik yang mempunyai bakat-bakat khusus bidang keagamaan, agar berkembang secara wajar dan optimal, bahkan diharapkan dapat dikembangkan lebih jauh sehingga menjadi hobi yang akan mendatangkan manfaat kepada dirinya dan banyak orang. Ketiga, fungsi perbaikan. Kurikulum PAI berfungsi untuk memperbaiki kesalahan, kekurangan, kelemahan peserta didik terhadap keyakinan, pemahaman, dan pengamalan ajaran agama islam dalam kehidupan sehari-hari, terutama dari segi keyakinan (akidah) dan ibadah. Keempat, fungsi pencegahan. Kurikulum PAI berfungsi untuk menangkal hal-hal negatif baik yang berasal dari lingkungan tempat

${ }^{21}$ Tim Gugus Tugas, Pengarusutamaan PRB, Strategi Pengarusutamaan Pengurangan Resiko Bencana di Sekolah, (Jakarta: Dirjen Manajemen Pendidikan Dasar dan Menengah Kemendiknas, 2010), h. 23-27.

22 TDMRC, "Walikota Banda Aceh, Buka Festival Sekolah Siaga Bencana",

http://www.tdmrc.org/id/walikota-banda-aceh-buka-festival-sekolah-siaga- bencana.jsp; lihat pula DetikNews, "12 Sekolah di Padang Jadi Pilot Project Kurikulum Siaga Bencana",

http://news.detik.com/read/2008/12/17/132427/1055104/10/12. Diakses pada tanggal 7 November 2016. 2006), h. 2

${ }^{23}$ Syaifuddin Sabda, Model Kurikulum Terpadu IPTEK dan IMTAQ, (Ciputat: Ciputat Press Group,

${ }^{24}$ E Mulyasa, Implementasi Kurikulum Tingkat Satuan Pendidikan: Kemandirian Guru dan Kepala Sekolah, (Jakarta: Bumi Aksara, 2008), h. 22.

25 Nazarudin, Manajemen Pembelajaran: Implementasi Konsep, Karakteristik dan Metodologi Pendidikan Agama Islam di Sekolah Umum, (Yogyakarta: Teras, 2007), h. 12. 
tinggalnya, maupun dari budaya luar yang dapat membahayakan dirinya sehingga menghambat perkembangannya menjadi manusia Indonesia seutuhnya. Kelima, Fungsi penyesuaian. Kurikulum PAI berupaya menyesuaikan dire dengan lingkungan baik lingkungan fisik maupun sosial dan pelan-pelan dapat mengubah lingkungannya sesuai dengan ajaran Islam. ${ }^{26}$

Berangkat dari temuan di lapangan, MIN Jejeran terkait kebijakan PRB, telah diintegrasikan secara signifikan melalui kurikulum maupun praksis dan teknis jangka panjang ke dalam desain PRB. PRB adalah usaha sadar dan terencana dalam proses pembelajaran untuk memberdayakan peserta didik dalam upaya pengurangan resiko bencana dan membangun budaya aman serta tangguh terhadap bencana. ${ }^{27}$ Tindakan dan kebijakan yang diambil oleh stakeholder sekolah tersebut sesuai dengan kebijakan-kebijakan yang bersifat nasional dan internasional, di antaranya adalah The Hyogo Framework for Action (HFA) 2005-2015. Seperti dijelaskan di awal, HFA ini berisi tiga tujuan strategi dan lima prioritas kegiatan untuk periode 2005-2015 ${ }^{28}$ kebijakan Aksi Reaksi Nasional Pengurangan Resiko Bencana (RAN PRB) 20062009 yang dikeluarkan oleh Bapennas, Peraturan Presiden No. 8 Tahun 2008 tentang Badan Nasional Penanggulangan Bencana, dan lain sebagainya.

Kebijakan pengintegrasian PRB melalui kurikulum ini merupakan bentuk pengamalan atas UU No.20 tahun 2003 tentang Sistem Pendidikan Nasional Pasal 38 Ayat (2), dimana dinyatakan di dalamnya bahwa, kurikulum pendidikan dasar dan menengah dikembangkan sesuai dengan relevansinya oleh setiap kelompok atau satuan pendidikan dan komite sekolah/madrasah di bawah koordinasi dan supervisi dinas pendidikan atau kantor departemen agama kabupaten/kota untuk pendidikan dasar dan provinsi untuk pendidikan menengah. ${ }^{29}$

Diantara sekolah di Indonesia yang telah mengadaptasi kebijakan pemerintah dalam PRB adalah MIN Jejeran, Pleret, Yogyakarta. MIN Jejeran telah mengintegrasikan PRB Gempa Bumi dalam kurikulum pendidikan ke dalam beberapa mata pelajaran, termasuk mata pelajaran pendidikan agama Islam. Di madrasah tersebut, kurikulum PAI yang relevan dengan PRB ada tiga mata pelajaran, yaitu al-Qur'an-Hadist, Aqidah-Akhlaq, dan Fiqih.

\section{PRB Berbasis Mata Pelajaran al-Qur'an dan Hadis}

Tema PRB Gempa Bumi terintegrasi dalam materi al-Qurean dan Hadis terutama diambil dari QS. al-Zalzalah dan al-Qari'ah. Metode yang digunakan dalam kegiatan pembelajaran antara lain adalah, ceramah interaktif, drill, tanya jawab interaktif, dan lain-lain. Metode ini dijelaskan Suratman:

Di antaranya Aqidah Akhlak, dengan al-Qur'an-Hadis tapi yang lebih menonjol yang berhubungan dengan gempa itu pelajaran al-Qur'an- Hadis. Materi dalam alQur'an-Hadis yang berhubungan dengan gempa bumi ada al-Qur'an tapi lebih ditekankan pada surat az-Zalzalah ${ }^{30}$

Menurutnya, dalam surat al-Zalzalah, yang secara bahasa berarti goncangan yang sangat dahsyat. Dalam konteks pendidikan bencana, anak-anak diajak membayangkan tentang kondisi ketika terjadi gempa. Dalam kegiatan tersebut, bencana yang pernah mereka alami dibayangkan selama beberapa saat. Hal ini ditujukan agar anak-anak lebih siap dan waspada, serta banyak berdoa memohon kepada Allah agar diberi ketenangan dan keselamatan. Sebelum melaksanakan pengajaran, Suratman menganalisis beberapa KD yang bisa diintegrasi dalam Rencana Pelaksanaan Pembelajaran (RPP). Metode yang digunakan adalah ceramah interaktif,

\footnotetext{
${ }^{26}$ Ramayulis, Metodologi Pendidikan Agama Islam, (Jakarta: Kalam Mulia, 2005), h. 21.

${ }^{27}$ Ariantoni, dkk, Modul Pelatihan..., Ibid, Hal. 28.

${ }^{28}$ Mengenai butir-butir kesepakatan dalam Hyogo Framework for Action (HFA).

${ }^{29}$ Lihat: UU No 20 Tahun 2003 tentang Sistem Pendidikan Nasional ......

${ }^{30}$ Wawancara dengan Suratman, Guru MIN Jejeran Bantul, Sleman, pada tanggal 9 November 2016.
} 
yang menghasilkan umpan balik, dan tanya jawab mengenai segala permasalahan yang berkaitan dengan PRB secara menyeluruh. ${ }^{31}$ Dalam RPP materi al-Qur'an-Hadist ini berisi perintah tersirat agar manusia senantiasa berusaha mengurangi resiko ancaman bencana. Manusia diminta selalu berbuat baik dengan sesama sebagaimana Allah berbuat baik terhadap mereka serta larangan untuk berbuat kerusakan di muka bumi.

Dalam beberapa ayat al-Qur'an mengajarkan kepada manusia agar tidak menggunakan sumber daya alam secara berlebihan. Hukum Islam tidak menyalahkan fungsionalisasi sumber daya alam untuk kepentingan pribadi dan kolektif warga negara. Namun Islam melarang eksploitasi berlebihan terhadap sumber daya alam. Eksploitasi berlebihan akan berdampak pada terjadinya bencana. Sebagaimana firman Allah dalam QS an-Nahl: 112 Pada bagian lain terdapat ayat yang secara gamblang menekankan pentingnya merawat serta menjaga lingkungan, baik melalui penghijauan, konservasi hutan dan segala upaya yang memungkinkan terpeliharanya lingkungan hidup dan sumber daya alam. Perintah tentang perlunya menjaga alam dan lingkungan hidup dalam al- Qurean dilandasi argumentasi teologis yang logis. Pertama, bahwa semua makhluk, baik yang hidup maupun benda mati, bertasbih kepada Allah swt. Hal ini sebagaimana firman Allah dalam QS al-Isra':44 yang artinya:

Langit yang tujuh, bumi dan semua yang ada di dalamnya bertasbih kepada Allah. dan tak ada suatupun melainkan bertasbih dengan memuji-Nya, tetapi kamu sekalian tidak mengerti tasbih mereka. Sesungguhnya Dia adalah Maha Penyantun lagi Maha Pengampun.

Kedua, alam memiliki kehidupan. Ia mempunyai perasaan dan terpengaruh oleh sikap makhluk hidup di sekelilingnya. Misalnya, gunung mematuhi perintah Allah untuk tunduk; burung patuh kepada-Nya; langit dan bumi menangis akibat kedzaliman yang dibuat oleh manusia. Hal ini digambarkan Allah dalam QS. al-Saba ${ }^{e e} 10$ yang artinya:

Dan sesungguhnya telah Kami berikan kepada Daud kurnia dari kami. (kami berfirman):

"Hai gunung-gunung dan burung-burung, bertasbihlah berulang-ulang bersama Daud", dan

Kami telah melunakkan besi untuknya.

Demikian juga dalam QS ad-Dukhan: 29

Maka langit dan bumi tidak menangisi mereka dan merekapun tidak diberi tangguh.

Selain mengajarkan manusia untuk melakukan ikhtiar fisik, al-Qur'an juga memerintahkan manusia untuk melaksanakan ikhtiar spriritual, sebagaimana terdapat dalam QS. al-Anbiya: 83. Hadis sebagai fungsi penjelas (mubayyin) terhadap al-Qur'ean juga memuat banyak perintah untuk menempuh berbagai tindakan preventif terhadap ancaman bencana. Di antara hadis masyhur yang terdapat dalam Shahih Bukhari ار ارا اولاض ار ار اض لا (Tidak boleh ada bahaya yang menimpa diri sendiri maupun orang lain).

Selain mengajarkan tindakan preventif sebelum bencana terjadi, hadis juga memberikan bagaimana seseorang muslim harus bertindak pasca terjadinya gempa bumi. Di antara Hadis yang relevan tengan isu bencana adalah diriwayatkan oleh Ibnu Abbas RA sebagai berikut:

Ibnu Abbas berkata: Tidak berhembus angin sedikitpun kecuali Nabi SAW berlutut di atas kedua lututnya, seraya berdoa: "Ya Allah jadikan ia rahmat dan mangan jadikan ia siksa." Riwayat Syafi'i dan Thabrani. Dari Beliau: Bahwa beliau sholat dengan enam ruku' dan empat sujud ketika terjadi gempa bumi, dan beliau bersabda: "Beginilah cara sholat (jika terlihat) tanda kekuasaan Allah."

${ }^{31}$ Wawancara dengan Suratman, ...... 
Diriwayatkan oleh Baihaqi. Syafi'i juga menyebut hadits seperti itu dari Ali Ibnu Abu Thalib namun tanpa kalimat akhirnya. ${ }^{32}$

Hadis di atas secara jelas memaparkan bagaimana Nabi memberikan teladan agar bagaimana seorang muslim bertindak ketika terjadi bencana gempa bumi.

\section{PRB berbasis Mata Pelajaran Aqidah Akhlak}

Materi Aqidah Akhlak yang diajarkan MIN Jejeran lebih ditekankan pada pengajaran sikap optimis dalam kehidupan sehari-hari. Bagian dari sikap ini adalah memperbanyak kalimat thayyibah serta iman pada hari akhir. Metode yang digunakan hampir sama dengan metode kegiatan pembelajaran al-Qur'an-Hadis. Dalam hal ini, Suratman menegaskan:

\section{Pada Aqidah Akhlak banyak materi yang relevan dengan PRB namun pada keoptimisan, iman pada hari akhir, dan memperbanyak kalimah thayyibah, lebih ditekankan. ${ }^{33}$}

MIN Jejeran dalam RPP materi Aqidah Akhlaq memuat PRB tentang Gempa Bumi terintegrasi dalam mata pelajaran tersebut. Kompetensi tersebut dicapai melalui indikator yang menjelaskan pengertian optimis, praktek optimis, hikmah berlaku optimis dalam menghadapi bencana, termasuk gempa bumi, dan mengenal cara-cara penyelamatan diri dalam bencana.

Fungsi dan manfaat dari pengajaran Aqidah Akhlak ini berdampak langsung terhadap pola fikir dan tindakan siswa yang terlihat semakin optimis menghadapi bencana. Sebagian besar siswa terlihat semangat saat peneliti berbincang dengan mereka. Selain itu, para siswa menjawab dengan antusias saat ditanya berbagai hal terkait dengan PRB, khususnya isu gempa bumi. Tidak hanya semangat diwawancarai, bahkan para siswa dengan sigap mempraktekkan cara menyelamatkan diri di bawah meja. Selain itu, beberapa siswa tanpa dikomando juga menunjukkan denah maupun peta evakuasi saat terjadi bencana. ${ }^{34}$ Rifki, salah seorang murid megatakan:

Teman-teman banyak diajari ayat-ayat al-Qur'an-Hadist mengenai itu loh bahaya gempa bumi. Kita mendengarkan dan akhirnya faham... oh Allah sebenarnya sudah mengingatkan hamba-Nya tentang Gempa Bumi.... 35

Kebijkan PRB ke dalam kurrikulum dapat dirasakan secara langsung manfaatnya oleh para siswa. Pengajaran Aqidah Akhlak terhadap anak-anak merupakan pengajaran yang mempunyai nilai lebih. Masa kanak-kanak merupakan saat seseorang membentuk karakter dalam mencoba hal-hal baru. Karena itu, berbagai kebijakan sekolah secara konseptual (kurrikulum PRB) diikuti dengan langkah konkrit di lapangan mendapat respon positif para siswa. Dinamika antusiasme para guru maupun siswa tergambar dengan jelas di MIN Jejeran, baik dalam mengikuti pelajaran terkait dengan PRB Gempa Bumi maupun pada saat mereka diajari praktek pencegahan bencana ini. ${ }^{36}$ 1996), h. 63 .

${ }^{32}$ Ibn Hajar al-Asqalani, Bulugh al-Maram min Adilat al-Ahkam, (Surabaya: Maktabah Balai Buku,

${ }^{33}$ Wawancara dengan Surahmat..... .

${ }^{34}$ MIN Jejeran tidak hanya melakukan PRB dalam kurrikulum saja. Kebijakan PRB yang dilakukan oleh sekolah juga dibarengi dengan tindakan (action) konkrit yang menggambarkan sekolah tersebut betul-betul sebagai sekolah siaga bencana. Selain denah evakuasi yang terpampang di setiap sudut sekolah juga dijumpai di banyak hal lain. Di setiap sudut ruang kelas, mulai dari penataan meja-kursi, almari, hingga papan tulis disesuaikan dengan standar gempa bumi. Artinya, jika tiba-tiba terjadi gempa bumi tidak berbahaya terhadap keselamatan murid. Bahkan penataan parkir sepeda maupun motor juga disesuaikan dengan standar pengamanan gempa bumi.

${ }^{35}$ Wawancara dengan Muhammad Rifki, siswa kelas VI MIN, Jejeran, tanggal 28 November 2016.

${ }^{36}$ Wawancara penulis dengan Suratman di MIN Jejeran pada tanggal 29 November 2016. 
Pada mata pelajaran Aqidah Akhlak memiliki arti penting lain terkait dengan PRB berbasis gempa bumi. Stressing point pada materi ini mengajarkan agar peserta didik senantiasa menganut aqidah yang lurus dan akhlak yang mulia. Beberapa point penting yang terkandung dalam buku ajar mata pelajaran Aqidah-Akhlaq berisi pesan penting peran manusia sebagai khalifah di bumi. Alam beserta isinya adalah tanggung jawab manusia sebagai khalifah di muka bumi. Pesan moral lainnya, manusia diharapkan mencintai alam dan selalu berusaha merawatnya, menjaga keselamatan diri, menolong sesama, bahkan mementingkan orang lain atas dirinya sendiri. ${ }^{37}$ Pesan moral berbasis spiritual Islam ini menjadi basis teologis para guru dalam proses indoktrinasi PRB Gemba Bumi bagi para siswa di MIN Jejeran.

Dalam salah satu bagian penting dalam buku ajar tersebut ditegaskan makna penting peran manusia sebagai khalifah. Kekhalifahan manusia di muka bumi dijelaskan, bahwa Allah menciptakan manusia dari Adam sampai hari akhir nanti adalah agar manusia tidak hanya mengemban misi penghambaan kepada Allah, namun juga merawat alam dan tidak membuat kerusakan di dalamnya, karena alam beserta isinya diciptakan untuk kebutuhan mereka. ${ }^{38}$ Manusia diharuskan melakukan pekerjaan yang dapat menjamin berlangsungnya kelestarian alam dan setiap tindakan yang merusak alam dan berpotensi menimbulkan bahaya (hazard) bencana di dalamnya harus dihindari. Bentuk-bentuk tindakan hazard seperti eksploitasi gunung yang tidak proporsional dapat merusak ekosistem kestabilan bumi.

\section{PRB berbasis Mata Pelajaran Fiqh}

Dimensi fiqh dalam keseluruhan ajaran Islam menempati posisi penting. Jika dimensi ajaran tasawuf lebih menekankan aspek batin (esoteris), tetapi fiqh lebih menekankan dimensi dhohir (eksoteris). Fiqh lebih banvak berurusan dengan persoalan kehidupan sehari-hari umat Islam. Karena itu, dimensi ajaran fiqh dalam keseluruhan konstruksi ajaran Islam lebih menekankan aspek tatanan sosial-kemasyarakatan, bahkan kenegaraan. Karena itu, dimensi fiqh ini dikenal dengan ranah hukum positif. Ia mengatur kehidupan formal umat Islam secara horisontal (manusia dengan manusia dan manusia dengan alam) dan vertikal (manusia dengan Tuhan).

Dalam peran fiqh secara horisontal ini para ahli (ulama) melakukan upaya-upaya rekonstruksi ajaran Islam untuk menjawab problem kontemporer, termasuk isu bencana. Sebagian besar doktrin fiqh berisi tuntunan (tata cara) beribadah. Hal ini dengan mudah dapat dilihat pada khazanah kitab (kuning) klasik yang menjadi referensi pengajaran di pondok pesantren maupun lembaga pendidikan Islam lainnya. ${ }^{39}$ Tema-tema aktual sesuai dinamika problematika umat kontemporer tentu saja belum terkodifikasi dalam hukum fiqh klasik, termasuk isu tentang bencana (Gempa Bumi) ini. ${ }^{40}$ Pada awal terjadinya berbagai bencana di Indonesia, berbagai ajaran Islam yang terkodifikasi baik fiqh, teologi maupun tasawuf tidak serta merta dapat dicarikan referensinya di dalam ajaran Islam. Berbagai fenomena problematika, termasuk isu bencana harus dicarikan dasar-dasar rujukan dalam ajaran Islam untuk selanjutnya direkonstruksi ulang dalam menjawab sekaligus sebagai refensi umat Islam.

${ }^{37}$ Secara lengkap dapat dilihat dalam materi ajar Aqidah-Akhlaq kelas VI di MIN Jejeran, Pleret, Yogyakarta, h. 38 .

${ }^{38}$ Materi ajar Aqidah-Akhlaq kelas VI di MIN Jejeran, Pleret, Yogyakarta, ..., h. 38-39.

${ }^{39}$ Fiqh klasik yang terkodifikasi dalam banyak kitab-kitab kuning di pesantren diproduksi pada abad ke16 hingga 18. Sebagian besar muatan isi kitab-kitab dimaksud lebih menekankan tata cara beribadah seperti hukum bersuci, tata cara shalat, puasa, haji, dan sebagainya. Menyebut di antara kitab-kitab kuning tentang fiqh yang matig diajarkan secara kontinyu hingga saat ini di sebagian besar pondok pesanten dan lembaga pendidikan Islam hingga kini adalah kitab al-Syakh Sulam al-Taufiq, Fath al-Qorib, dan masih banyak lagi. Lihat: al-Sulam alTaufiq, Muhammad Nawawi, Darul Ihya' al-Kutub al-Arabiyah, tt. Check juga: Fath al-Qorib al-Mujib, Muhammad Ibnu Qosim al-Ghazi, Darul Ihya' al-Kutub al-Arabiyah al-Indonesia, tt.

${ }^{40}$ Rubaidi, Islam, Kyai, dan Fenomena Bencana: Studi tentang Konstruksi Fiqh Kyai tentang Bencana di Jember, Jawa Timur, Penelitian Individual, (Yogyakarta: CRCS-UGM, 2008). 
Mata pelajaran fiqh dalam konteks PRB gempa bumi di MIN Jejeran dijelaskan seperti analisis di bawah ini. Fiqh merupakan suatu tuntunan bagi umat Islam dalam beribadah kepada Allah dan muamalah (horisontal) dengan sesama manusia. Mata pelajaran fiqh mengandung banyak materi yang sesungguhnya relevan dengan PRB. Bagian-bagian dari materi fiqh yang dapat direkonstruksi kedalam PRB adalah bagian yang mengajarkan hubungan manusia dengan sesama manusia (ibadah sosial). Cakupan materi ini dalam fiqh lebih besar dibanding bagian materi yang mengajarkan hubungan manusia dengan Allah (ibadah mahdlah). Materi fiqh yang relevan dengan PRB di antaranya adalah bahwa dalam kehidupan manusia harus senantiasa menjaga kebersihan secara umum baik diri maupun lingkungan. Selain itu, dalam fiqh juga terdapat bagian yang mengajarkan tentang muamalah. Pada bagian ini, manusia diharapkan agar selalu menjaga batasan-batasan yang telah ditetapkan dalam mengeksplorasi alam, dan tidak melakukan perilaku isrof (berlebihan) maupun tabdzir (penghamburan). ${ }^{41}$

Mata pelajaran fiqh mempunyai beberapa tujuan atau agenda besar, yaitu yang di dalam fiqh disebut dengan maqashid al-syari'ah (tujuan syariat). Maqashid al-syari'ah mencakup lima hal, yaitu menjaga agama (Hifdz al-Din), menjaga diri (Hifdz al-Nafs), menjaga akal (Hifdz $a l$-'Aql), menjaga keturunan (Hifdz al-Nasl), dan menjaga harta (Hifdz al-Mal). ${ }^{42}$ Lima maqashid di atas, dalam penerapannya banyak mempunyai kesamaan misi dengan PRB, di antaranya dalam hifdz al-Nafs misalnya, segala potensi dan kemungkinan yang dapat membahayakan diri sendiri maupun diri orang lain dan lain sebagainya harus dicegah. Prinsip ini sesuai dengan kaidah Usul al-Fiqh yang berbunyi; Daf'ul mafassid muqaddam ala Jalbi alMashalih (mencegah kerusakan lebih didahulukan daripada mengambil yang baik). ${ }^{43}$ Bahkan kelima maqashid di atas tidak mungkin terwujud tanpa adanya sarana alam yang tersedia. Sedangkan alam sendiri mengharuskan adanya perawatan agar tidak tertimpa bencana.

Pelajaran Fiqh terintegrasi dalam PRB tidak hanya berhubungan dengan bencana gempa bumi saja. Namun juga terkait isu lingkungan yang lebih mendasar, misalnya penggunaan dan pengelolaan air secara optimal. Dalam upaya mensosialisasikan mata pelajaran Fiqh, Hanik mengatakan:

... nah, dari situ saya merasa lebih mudah mengintegrasikan PRB ke dalam pokok bahasan yng pertama, mandi besar pasca haid. Karena ketika mandi besar itu berhubungan dengan air, air itu adalah suatu benda yang bisa sangat bermanfaat bagi kita, juga bisa menimbulkan bahaya bagi kita, untuk itu saya mudah mengintgerasikan PRB ke dalam pokok bahasan tersebut secara tekstual, maksudnya tekstual itu bisa saya perjelas ke dalam RPP. ${ }^{44}$

Metode dan tahapan yang digunakan dalam mata pelajaran tersebut, Hanik menambahkan bahwa, dalam pembelajaran selalu menggunakan multimetode, dalam arti guru tidak melulu ceramah, tetapi guru hanya memberikan pesan-pesan pokok apa yang harus dikerjakan oleh siswa. Di sini acuan yang dipakai adalah UU No. 20 Tahun 2003, bahwa dalam pembelajaran para guru harus memprioritaskan dan mengutamakan agar siswa membaca materi sebelum pembelajaran dimulai. Di MIN Jejeran sudah disediakan buku untuk siswa, satu banding satu, dan siswa mempunyai buku pengayaan masing-masing dengan membeli satu persatu ${ }^{45}$ Dalam hal ini, guru meminta siswa untuk memperdalam apa yang ada di dalam buku tersebut di kelas. Untuk itu dalam pembelajaran di MIN Jejeran, siswa akan diminta untuk membaca materi

${ }^{41}$ Lihat: Materi Bahan Ajar, Pelajaran Fiqih dalam Pengurangan Resiko Bencana (PRB), MIN Jejeran, Pleret, Yogyakarta, 2014.

42 Abdul Wahab Khalaf, Ushul al-Fiqh, Dar al-Kutub al-Ilmiyah, (Beirut, Lebanon, 1997), h. 31.

${ }^{43}$ Abdul Wahab Khalaf, Usher al-Fiqh, ......., h. 33.

${ }^{44}$ Wancara dengan Hanik, Guru Pendidikan Agama Islam (PAI), tanggal 29 November 2016.

${ }^{45}$ Wawancara dengan Hanik, Guru Pendidikan Agama Islam (PAI), tanggal 29 November 2016. 
terlebih dahulu, kemudian diberi tugas berupa mengambil poin-poin materi yang telah dibaca, jadi semacam inquiry, dengan metode diskusi atau diskusi berpasangan. ${ }^{46}$

Diskrispi di atas merupakan potret atau bentuk affirmative action secara nyata lembaga pendidikan Islam ikut berperan dalam upaya pengurangan resiko bencana (PRB). Bencana Gempa Bumi di Yogyakarta maupun di belahan Indonesia lainnya secara potensial masih sangat mungkin terjadi. Baru saja, 28 September 2018, di Donggala, Palu, dikejutkan dengan gempa bumi dengan kekuatan 7,4 skala richter yang diikuti gelombang tsunami menyapu sebagian besar Donggala dan Ibu Kota Palu, Sulawesi Tengah. Puluhan ribu jiwa melayang secara siasia. Hanya dalam hitungan bulan, sebelumnya selama beberapa bulan, Lombok Utara juga digoncang berkali-kali gempa. Walaupun tidak diikuti tsunami, tetap saja merenggut ratusan jiwa manusia dan puluhan ribu rumah penduduk hancur berantakan.

Upaya mitigasi maupun pengurangan resiko bencana yang dilakukan oleh MIN Jejeran, Yogyakarta, menjadi model sikap kewaspadaan dalam menghadapi hazard (ancaman) yang sewaktu-waktu dapat menghadirkan bencana bagi masyarakat. Edukasi kebencanaan melalui stakeholder pendidikan, tidak hanya akan menyelamatkan ribuan peserta didik. Lebih dari itu, para peserta didik dapat menjadi agent of transformation bagi keluarga maupun masyarakat di setiap lingkungan peserta didik.

\section{Penutup}

Pengurangan Resiko Bencana (PRB) berbasis integrasi kurikulum pendidikan terbukti secara signifikan bermanfaat dalam diseminasi, edukasi, bahkan tindakan praksis dalam penanganan kebencanaan. PRB dalam konteks Gempa Bumi ke dalam kurikulum Pendidikan Islam (PAI) di MIN Jejeran, Pleret, Bandul, Yogyakarta merupakan sedikit dari succes story (cerita sukses) tentang peran-peran lembaga pendidikan dalam partisipasi terhadap PRB bagi masyarakat melalui para siswa. Upaya yang dilakukan oleh MIN Jejeran ini melalui proses panjang; dimulai dari kesadaran pihak internal (pemangku kepentingan sekolah), hadirnya pihak ke-3 (Plann Internasional), hingga penyusunan kurrikulum dan diteruskan dengan praktek nyata dalam bentuk simulasi maupun berbagai tindakan nyata lainnya.

Pendidikan Agama Islam (PAI) menjadi kata kunci sebagai identitas dari eksistensi lembaga sekolah yang bernama MIN (Madrasah Ibtida'iyah Negeri) dalam partisipasi aktif terhadap PRB, khususnya dalam hal bencana Gempa Bumi sebagai pengalaman empirik masyarakat Yogyakarta paska peristiwa Gempa Bumi 27 Mei 2006, tepatnya di Bantul, Yogyakarta yang dampaknya juga di daerah lain seperti Klaten, Temanggung, Magelang, Semarang, dan sebagainya.

Materi (mata pelajaran) PAI terbukti dapat dielaborasi secara konseptual maupun praksis dalam upaya-upaya pengurangan hazard (ancaman) maupun vulnerability (kerentanan) masyarakat dalam menghadapi bencana (khsususnya Gempa Bumi). PAI secara signifikan memiliki peran dalam jangka pendek, menengah, dan panjang bagi para siswa dalam proses maupun tahapan penting terkait dengan diseminasi, edukasi, sosialisasi, bahkan praksis kebencanaan.

Konseptualisasi PAI dalam PRB ini tentunya tidak dapat dilepaskan dari upaya-upaya sistemik-konseptual sebelumnya yang telah dirancang oleh para pihak. Berbagai upaya dimaksud adalah lahirnya berbagai deklarasi, kesepakatan, maupun perundang-undangan, bahkan keputusan terkait dengan fenomena kebencanaan. Lahirnya Hyogo Framework Action (HFA), Rencana Aksi Nasional (RAN), UU No. 24 tahun 2007, hingga Keputusan Kemendiknas dalam PRB menjadi landasan bagi lahirnya kebijakan MIN Jejeran PRB Gempa Bumi berbasis kurrikulum PAI.

${ }^{46}$ Wawancana dengan Hanik, ....... 
Al Izzah: Jurnal Hasil-Hasil Penelitian-ISSN: 1978-9726 (p); 2541-0717 (e)

Volume 13, Nomor 2 (November, 2018)

\section{Daftar Pustaka}

Ariantoni, dkk. Modul Pelatihan Pengintegrasian Pengurangan Resiko Bencana (PRB) ke Dalam Sistem Pendidikan. Jakarta: Pusat Kurikulum Balitbang Kemendiknas, 2009.

Direktorat Jenderal Management Pendidikan Dasar \& Menengah. Strategi Pengarusutamaan Pengurangan Resiko Bencana di Sekolah. Jakarta: Kementerian Pendidikan Nasional, 2010.

Desfandi, Mirza. "Urgensi Kurikulum Pendidikan Kebencanaan Berbasis Kearifan Lokal di Indonesia". Jurnal Sosio Didaktika, Vol. 1, No. 2 (Desember 2014).

E Mulyasa. Implementasi Kurikulum Tingkat Satuan Pendidikan: Kemandirian Guru dan Kepala Sekolah. Jakarta: Bumi Aksara, 2008.

Hasanah, Iswatul, Sri Wahyuni, Rayendra Wahyu Bachtiar. "Pengembangan Model Mitigasi Bencana berbasis Potensi Lokal yang Terintegrasikan ke dalam Kurikulum IPA di SMP”, Jurnal Pendidikan Fisika, Vol. 5, No. 3 (Desember 2016).

Honesty, Leli dan Nazwar Djali. "Pendidikan Kebencanaan Di Sekolah-Sekolah Di Indonesia Berdasarkan Beberapa Sudut Pandang Disiplin Ilmu Pengetahuan", Jurnal Momentum, Vol. 12, No. 01 (Februari 2012).

Ibn Hajar al-Asqalani. Bulugh al-Maram min Adilat al-Ahkam. Surabaya: Maktabah Balai Buku, 1996.

Khalaf, Abdul Wahab. Ushul al-Figh, Dar al-Kutub al-Ilmiyah, Beirut, Lebanon, 1997.

Konsorsium Pendidikan Bencana Indonesia. Kerangka Kerja Sekolah Siaga Bencana. Jakarta: KPB, 2011.

Materi ajar Aqidah-Akhlaq kelas VI di MIN Jejeran, Pleret, Yogyakarta, 2014.

Materi Bahan Ajar, Pelajaran Fiqih dalam Pengurangan Resiko Bencana (PRB), MIN Jejeran, Pleret, Yogyakarta, 2014.

MDGs Support Unit. Millenium Development Goals. Jakarta: UNDP, t.t.

Muhammad Ibnu Qosim al-Ghazi, Fath al-Qorib al-Mujib. Darul Ihya' al-Kutub al-Arabiyah al-Indonesia, tt.

Muhammad Nawawi, al-Sulam al-Taufiq, Darul Ihya' al-Kutub al-Arabiyah, tt.

Nazarudin. Manajemen Pembelajaran: Implementasi Konsep, Karakteristik dan Metodologi Pendidikan Agama Islam di Sekolah Umum. Yogyakarta: Teras, 2007.

Pribadi, Krisna S. Konsep Pengelolaan Bencana, Makalah TOT Pengelolaan Resiko Bencana Berbasis Pesantren Nahdlatul Ulama. Bandung: Pusat Mitigasi Bencana ITB Bandung, 2007.

Rahma, Aldila Rahma. "Implementasi Program Pengurangan Risiko Bencana (Prb) Melalui Pendidikan Formal”. Jurnal Varia Pendidikan, Vol. 30, No. 1, (Juli 2018): 1-11. 
Al Izzah: Jurnal Hasil-Hasil Penelitian-ISSN: 1978-9726 (p); 2541-0717 (e) Volume 13, Nomor 2 (November, 2018)

Ramayulis. Metodologi Pendidikan Agama Islam. Jakarta: Kalam Mulia, 2005.

Rubaidi, Islam, Kyai, dan Fenomena Bencana: Studi tentang Konstruksi Fiqh Kyai tentang Bencana di Jember, Jawa Timur. Penelitian Individual, CRCS-UGM, 2008.

Sabda, Syaifuddin. Model Kurikulum Terpadu IPTEK dan IMTAQ. Ciputat: Ciputat Press Group, 2006.

Tim Gugus. Tugas Pengarusutamaan PRB, Strategi Pengarusutamaan Pengurangan Resiko Bencana di Sekolah. Jakarta: Dirjen Manajemen Pendidikan Dasar dan Menengah Kemendiknas, 2010.

\section{Undang-Undang;}

Undang-Undang Nomor 24 tahun 2007 tentang Penanggulangan Bencana.

Undang-undang (UU) Nomor 7 tahun 2012 tentang Penanganan Konflik Sosial. Dengan lahirnya UU No 7 tahun 2012.

Undang-undang (UU) Nomor 9 tahun 2013 tentang Pencegahan dan Pemberantasan Tindak Pidana Pendanaan Terorisme.

Surat Edaran Menteri Pendidikan Nasional No.70a/SE/ MPN-/2010.

\section{Website;}

Amsa, Seefudin. "sekolah-berbasis-pengurangan-resiko-bencana mungkin- kah" www.umum.kompasiana.com/2009/05/25/ -6223.html. Diakses tanggal, 28 Desember 2016.

IDN Times, 5 Hal Mengenai Gempa Bumi Yogyakarta Pada Tahun 2006. http://www.rappler.com/indonesia/134463. Diunduh pada tanggal 15 Mei 2017.

Fakhri, Fakhrizal. "Berada di Ring of Fire, ESDM Sebut Seluruh Wilayah Indonesia Rawan Gempa”. OKEZONE NEWS, Rabu 03 Oktober 2018.Diunduh tanggal 5 Oktober 2018.

TDMRC, "Walikota Banda Aceh, Buka Festival Sekolah Siaga Bencana", http://www.tdmrc.org/id/walikota-banda-aceh-buka-festival-sekolah-siagabencana.jsp. Diakses pada tanggal 7 November 2016.

DetikNews, "12 Sekolah di Padang Jadi Pilot Project Kurikulum Siaga Bencana”, http://news.detik.com/read/2008/12/17/132427/1055104/10/12. Diakses pada tanggal 7 November 2016.

\section{Surat Kabar;}

Harian Kedaulatan Rakyat, "Delegasi Kementerian se-Asia Pasifik ke MIN Jejeran”, terbit tanggal 23 Oktober 2012. 